Meta

Journal des tradlucteurs

Translators' Journal

\title{
The Disease of Translation
}

\section{Glen Shortliffe}

Volume 14, numéro 1, mars 1969

URI : https://id.erudit.org/iderudit/004138ar

DOI : https://doi.org/10.7202/004138ar

Aller au sommaire du numéro

Éditeur(s)

Les Presses de l'Université de Montréal

\section{ISSN}

0026-0452 (imprimé)

1492-1421 (numérique)

Découvrir la revue

Citer cet article

Shortliffe, G. (1969). The Disease of Translation. Meta, 14(1), 22-26.

https://doi.org/10.7202/004138ar d'utilisation que vous pouvez consulter en ligne.

https://apropos.erudit.org/fr/usagers/politique-dutilisation/ 


\section{grogerson \\ the disease \\ of translation}

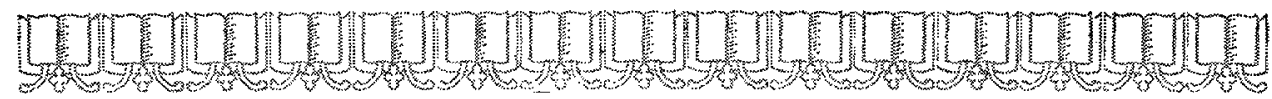

"For this half-year I have been troubled with
the disease of Translation."

DRYDEN

In a bicultural situation the traditionally ungrateful task of the translator is fraught with peculiar perils. The real possibility that a provincial statesman's modest desire to «emphasize a request » may reach the ears of most of his countrymen as a determination to «insist upon a demand» gives a uniquely Canadian twist to the old saw: «traduttore, traditore». Much can be forgiven the hurly-burly of everyday journalism, where some communion (if not community) of material interest may in any case soften the impact of scrambled transmission. The more rarefied realm of creative literature, where a people speaks its soul, imposes its own imperatives.

It is a commonplace that every human language opens another window upon reality. History, which rejoices in the improbable, has chosen to intertwine two destinies in this country in fine disregard for the fact that the French and English windows upon the world are sometimes so diametrically positioned as to present landscapes from two different planets. In our national circumstances the literary translator is more than ever called upon to do something more than transport or transplant. A rose, even by the same name, may not after all smell as sweet when lifted bodily into another soil and atmosphere; at any rate it is unlikely to smell the same, if only because a rather different person is smelling it. If the translator can grasp the effect of the rose and successfully create a parallel effect elsewhere, who is to gainsay him, even if the original flower appears to disappear in the process? The search for total meaning may on occasion entail nothing less than a kind of molecular breakdown followed by an act of reconstitution that offers the widest scope to the creative imagination. These instances are the more frequent as the original is the more "artistic " in the sense of having powerfully exploited the distinctive poetic capacities of its own idiom.

At this point, in my view, the translator either asserts his unabashed 
individuality or consents by default to fall short of his purpose. Slavish fidelity to literal detail can be treason to the overall literary effect, and I for one would resolve this apparent conflict of loyalties in the direction of the widest latitude. Traduction is more than translation (as the French has it) and there are times when the original text needs to be pushed to the very brink of the barrier beyond which its author (who must, I suppose, be allowed a few rights still) can legitimately complain that he is being "traduced» (as the English has it).

This permissive view of the translator's prerogatives is not as radical as the bald terms of my proposition might appear to suggest. Excellent European precedents exist - a matter of concern, I know, to Canadians of both national persuasions. Consider Taine's masterful rendering of Macauley's assault upon the apologists of Charles the First: «And what, after all, are the virtues ascribed to Charles ? ... a few of the ordinary household decencies which half the tombstones in England claim for those who lie beneath them!» Is Taine to be damned for having ruthlessly expunged the fair name of England to give the French reader: «... la moitié des pierres tumulaires réclament chez nous ...»? Quite the contrary, surely, for the word Angleterre must inevitably have awakened in the French ear overtones that are visibly absent from Macauley's particular context. Here, as so often in literary translation, the transmission of « something the same » demands the creation of « something different ».

The validity of these processes of fruitful substitution bears testimony to the simple truth that no language (not even a «dead $»$ one) exists in a cultural vacuum. Like the "meaning » of a nation's music, the «meanings » of its words (including the word «nation》 itself) are linked to the moods of a groupsubconscious by subterranean networks so complex as to thwart indefinitely any impulse to package linguistic phenomena into neat little parcels of cause and effect. In an infinity of relevant variables no single angle of analytical attack can offer more than a fleeting glimpse of what is going on below. Conceived as a reasoning craftsman, the ideal translator would need to be not only cultural historian, literary critic, philologist, phonetician, semanticist and structural linguist, but also sociologist, anthropologist, psychologist and psychoanalyst. Faced with the fact that translation does in fact occur, despite the evident impossibility of the translator being «all things to all men », we are forced to the conclusion that bare logic is as insufficient to the art of translation as to any of the more usual forms of creative writing, - a cheerful thought that would seem to rule out any immediate threat of technological unemployment in the literary field, whatever the more pedestrian applications of the translation machine. In the arts, it would appear once more, no reasonable substitute has yet emerged for the personal intuition which is the fruit of cultural immersion.

This is not to suppose that the translator's procedures are contrary to logic or that they cannot be explained after a fashion, and usually after the event. Consider the remark above about being « all things to all men ». An equivalent French, in the context, might be: "contenter tout le monde et son père ». It would be perfectly sensible, of course, to invoke the different impacts of King James and Douai Bibles upon the vulgates of Protestant England and Catholic France, entirely reasonable to inject some considerations on the relative influences 
of Elizabethan literature and the Age of Louis XIV. The working translator is unlikely to have consciously plodded through all that; yet his «intuitive 》 leap from Saint Paul to La Fontaine reflects something more than familiarity with the mechanics of another tongue. The processes involved may help to explain the despair of language teachers confronted with bright young adults professing total indifference to literary history, yet pathetically eager to «learn to speak French».

Mechanical structure itself, of course, reflects centuries of unconscious response to evolving needs of expression and communication in particular cultural situations. Given the infinity of variables already mentioned we are fortunate in being able to enjoy the game without having to know all the rules, and may affirm our sense of the inseparability of all these elements without incurring thereby the obligation of explaining precisely how they are connected. Still, a few logical relationships are visible to the speculative eye. I expect most English-speaking schoolboys have been struck, on their first exposure to French, by the curious invitation to recognize a verb by the end of the word. Aside from the ubiquitous present participle, the English verb «system» (if it deserves the name) offers nothing comparable to the regular -er, -ir, -re, -oir of even the French « irregulars». As generations of baffled headline readers will attest, the English word «sound », for example, may be verb or noun or adjective. But then French, with its leveling stress, has nothing to match the undulating vocal inflections of English with all that wealth of semantic implication which makes us extract an extract and contract a contract, a pattern so closely woven into the genius of English that even in popular speech we sense that when we come down we've had a bit of a comedown. These vocal effects have important consequences for the translator because the literary language, as distinct from the more commonplace «written tongue », derives its poetic force from an appeal that is ultimately aural even when unspoken.

At least a few of these consequences are readily predictable. Let us return, for example, to this matter of tonic accent. In French, the vowels enjoy a kind of republican equality, while in English they stand mute before the syllable that has been crowned by a fixed stress. A comparison of Canada (kanadá) with «Canada (kánada - often even kánda, in quite respectable mouths) will make the point. Probably some obscure law relative to the conservation of energy is at work here, but no matter. The same example will serve to remind us that the French stress, while variable within limits and lighter than the English, generally falls toward the end of the word rather than the beginning, as any English Canadian becomes at least vaguely aware whenever he intones the National Anthem. To me this French predilection for full vowels and emphatic final syllables suggests a primary pattern of assonance, while English, with its taste for consonants and heavy-footed initial syllables, seems predisposed to alliteration. Now it so happens that the early literary monuments of each culture display naïve poetic impulses that are admirably consistent with such a view of things - no justification, I hasten to agree, for playing the linguistic Leibnitz with vain assertions that «things could not have been otherwise than as they are»; yet the fact remains that la Chanson de Roland assonates where Beowulf alliterates, and I think the translator is entitled to draw a usable inference if he feels like it, to the point of going forth and doing likewise if literary circumstance appears to warrant. 
Of course this kind of equation describes only one of an unlimited family of curves that define the patterns of the two languages. As has been noted, the more poetic a text the more closely will $n$ approach infinity, and by the nature of things the translator can be consciously aware of only a few. The degree to which he intuitively «feels» the others will determine his success in setting up on his own terrain a creation that imparts the sound, the colour and the energy which comprise the total sense of the original. In this process the thing I have called the "equation » serves only as a point of departure, and I hope my own use of the alliterative device to set the underlying tone of the English version of l'Incubation will not be taken to indicate any facile assumption on the part of the translator that the poetic power of Bessette's strangely beautiful novel can be encapsuled within so simple a formula. Still he did write it in French, after all, a fact of no mean consequence. Consider the implications of his highly original use, in place of the more prosaic imperfect tense, of a sweeping series of present particip'es (almost "un-French», this; perhaps biculturally Canadian? - the mind boggles at the speculative possibilities!): "... le troupeau piétinant... poussant de temps en temps un juron ... échangeant de brèves remarques... se tenant par la 'main ... n'ayant pas de main à tenir ... souffrant ... espérant ... se disant que ce péril de tous les instants ... »

Here is a technique consciously chosen to fit the author's purpose to sustain the headlong pace of an impetuous flow of incident. (As he has put it himself: "There are times when the pronoun is an interruption. ») But my immediate point lies elsewhere: in the strong sense of hallucinatory incantation produced by the assonating effect (even riming, in this instance) of all those stressed participial -ants, fortified further by a sprinkle of instants and de temps en temps. Knowing that no possible accumulation of unstressed «-ings » could ever deliver the same effect to the English ear, the translator may well feel drawn back to those beginnings where lies the lure of alliteration. One thing at least he knows, and that is that he must choose to go somewere. He cannot stay where Bessette has put him if he is to do justice to Bessette.

Far from entailing any gross distortion of the original text this wide-ranging quest for compensatory substitutes is entirely compatible with a special kind of precision which, if my case is sound, is the important kind in the translation of literary works. A brief comparison may help to resolve the apparent paradox of this double claim to freedom and precision at the same time. In the extracts that follow I have numbered and bracketed the corresponding elements to clarify lines of connection which might be obscured by transpositions of order:

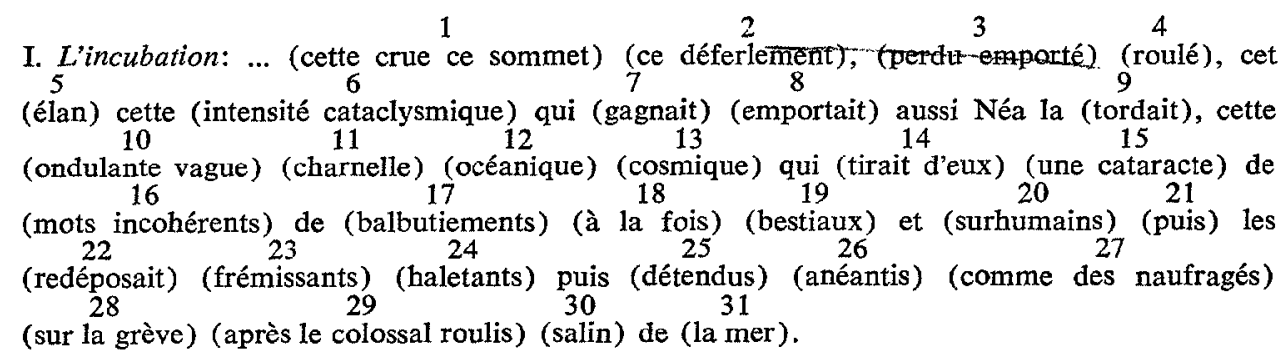




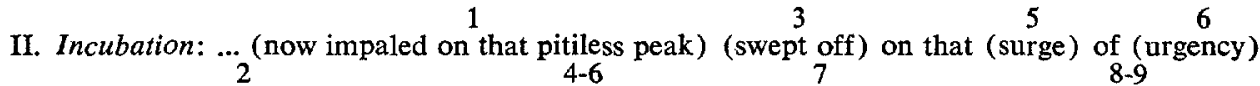
that (crash of cresting foam) (rolling relentlessly) (catching up) Nini too (whirling) her 9
(writhing) (away) $\underset{14}{10-12} \begin{gathered}12-13 \\ 15\end{gathered}$ on that (tidal wave) (rising from) the (cosmic) (recesses of the flesh) (ripping from their lips) a (torrent) of (stuttered) (syllables) (half) (bestial) (half) (celestial)

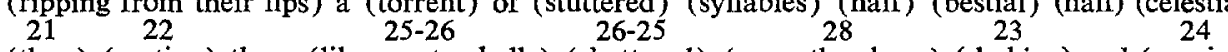
(then) (casting) them (like empty shells) (shattered) (upon the shore) (shaking) and (gasping) (like shipwrecked survivors) (borne by the breakers) of the (salted) (sea).

None of this is designed to argue that the instruments of an orchestra are entitled to go where they like so long as they finish together, but only to point to the futility of assigning the tuba part to the piccolo. These two instruments cannot be expected to produce the same sound even when they play the same tune. I am even prepared to enter a plea for permission to add a few grace notes on occasion, when they are naturally suited to the instrument at hand and harmoniously attuned to the overall mood of the composition. I recall a very brief quandary at a point in Bessette's le Libraire where a cynically unenthusiastic Jodoin finds his bed invaded by an overaccommodating landlady. "J'ai dû m'exécuter », he shrugs in the original. Need I confess that in the presence of the overwhelming urge to make this: "It was up to me to rise to the occasion 》, I was impelled to follow Oscar Wilde's notorious advice by yielding almost immediately. To those who may carp at this I can only reply that perceiving no betrayal either of the character of Jodoin or of the mood set by his creator, I remain obdurately uncontrite.

To put the matter squarely and without false modesty, the translator who takes on a work of art must aspire to a kind of artistry of his own if he is to show a decent respect for his model. This is in no way to lay claim to the exclusive domain of the original writer. That distinction remains forever obvious and peremptory: the one is primary where the other is secondary; the one initiatory, the other derivative; the one is synthetic before it is analytical, the other is just the opposite. Most significant of all, the translator needs none of the poet's or novelist's mysterious genius for generating something out of nothing. Therein, indeed, lies his incurable misfortune: denied the joys of conception, yet he is doomed to feel all the agonies of delivery. It would be foolhardy to pursue such a metaphor further. Suffice it to say that no amount of argument, logical or biological, will ever persuade the convalescent translator that he has not had a child of his own.

Glen ShortLiffe 